\title{
Editorial
}

\section{Honoring contributions of Richard A Lockshin to the field of cell death}

\author{
Z Zakeri $^{\star, 1}$ \\ Cell Death and Differentiation (2008) 15, 1087-1088; doi:10.1038/cdd.2008.35
}

On 10 December 2007, a scientific symposium was organized at The Rockefeller University by Zahra Zakeri and Hermann Steller to honor Dr. Richard Lockshin for his contributions to the field of cell death. Over 300 scientists attended this meeting. The speakers and chairs included distinguished scientists in the field, from 20 countries, who have contributed to this special issue. Richard Lockshin is one of the pioneers in the field of cell death contributing to the field for over the past 40 years and still remains one of the field's primary scientists. Rick was born in Columbus, Ohio in December 1937. His fascination and interest in the natural sciences from an early age led him to become a scientist. He obtained his bachelor's degree at Harvard University (1959), where he continued his doctoral studies with Carroll M Williams and received his PhD in 1963. The topic of his dissertation was published in a series of five landmark papers, beginning with 'Endocrine potentiation of the breakdown of the intersegmental muscles of silkmoths' coining the term 'programmed cell death' in $1964 .^{1-5}$ $\mathrm{H}$ Robert Horvitz (one of the recipients of the Nobel Prize in 2002) and Lockshin acknowledged the possibility that cell death may be regulated using nonmammalian model systems such as Caenorhabditis elegans and moths. This idea led to the elucidation of the genetic pathways of programmed cell death and has proven operative in mammals as well and has become a major area of scientific endeavor, as evidenced by the existence of this journal. Cell death is now the focus of much research not only in the area of basic science but also in understanding and controlling many diseases such as cancer, degenerative diseases, infection, and many others. Richard has studied the underlying mechanisms involved in programmed cell death using insects, and more recently, zebrafish, as model systems. He was among the first to report on alternative ways of cell death and the involvement of different proteases in cell killing. This finding now has blossomed into a major area of research in the field of cell death. His current research is a continuation of this in the developing embryo. Collaborating with several individuals, he was among the first to recognize and seek new proteins synthesized during programmed cell death; ${ }^{6,7}$ to study the physiology of dying cells and to question why they shrank; $;$ to recognize that the regulation of oncogenes was important in cell death; ${ }^{10}$ and to emphasize that not all deaths were by classical apoptosis. ${ }^{11}$

He continued to work on cell death and development, with a brief excursion into embryology, where he was among the first to initiate studies on gene activity in early embryos ${ }^{12}$ as a postdoctoral fellow at the University of Edinburgh until 1965. Upon his return to the United States, he took the position of Assistant Professor at the University of Rochester School of Medicine and Dentistry. He moved to St. John's University in 1975 as an associate professor, becoming a professor 1 year later, and served for 9 years as the chair of the department. $\mathrm{He}$ has mentored more than 30 graduate students and many undergraduates. He has been and remains a role model and a great help to young researchers and faculty all over the world. $\mathrm{He}$ has a tremendous love for teaching and it is this love that has made him the author of a book entitled 'The Joy of Science' to enlighten the students about the process of scientific inquiry. For his teaching, he has been honored with the Outstanding Achievement Award, St. John's University, 1987; the Presidential Award, Long Island University, 1987; and the Outstanding Achievement Award, New York City, 1982.

Another dimension of Richard's contribution to the field is his cofounding of the International Cell Death Society, for which he also served as President from 1998 to 2002. He has received the Society's award for 'great contributions to the field' given to a few others including Drs. John Kerr, Shigekazu Nagata, Peter Krammer, Junying Yuan, and Robert Horvitz. Richard, who is also the founding Chair of the first Gordon Conference on Cell Death, is on the Editorial Boards of Cell Death and Differentiation, Apoptosis, and the Journal of Biological Chemistry. He has served as the organizer and chair of numerous meetings in the field. In collaboration with Dr. Zahra Zakeri, he has established a focus group of researchers that work in enhancing scientific communication and knowledge to the third world countries and less privileged areas by the creation of the organization of Scientists Without Borders (Frontiers), whose aim is to advance teaching and scientific communication. A quotation from Richard Lockshin is the banner for the Scientists Without Borders group, which is as follows: 'Science should be like a monarch butterfly. It

\footnotetext{
${ }^{1}$ Department of Biology, Queens College and Graduate Centre of the City University of New York, Flushing, NY, USA *Corresponding author: Z Zakeri, Department of Biology, Queens College and Graduate Center of CUNY, 65-30 Kissena Blvd, Flushing, NY 11367, USA. Tel: + 718997 3417; Fax: + 718997 3429; E-mails: zahra_zakeri@ hotmail.com or Z.Z.Zahra_Zakeri@qc.edu
} 
should fly freely from country to country, tasting the sweetness of every land, and sharing its beauty with all.'

In addition to well over 100 publications, he has published more than six books in the field including the first comprehensive book in the field entitled Cell Death in Biology and Pathology on the study of cell death in the early 80 s, together with Ivor Bowen. More recently, he has coedited two other books on principles of cell death in collaboration with his wife and colleague Zahra Zakeri, which are used by many as handbooks on cell death.

The field of cell death is now one of the most dynamic and fast-moving areas of research, producing more than 50 publications a day. Richard's contribution to programmed cell death helped pave the way for the landmark studies by
Brenner, Sulston, and Horvitz, eventually leading to the Nobel Prize in Physiology or Medicine in 2002.

\footnotetext{
1. Lockshin RA, Williams CM. J Insect Physiol 1964; 10: 643-649.

2. Lockshin RA, Williams CM. J Insect Physiol 1965a; 11: 831-844.

3. Lockshin RA, Williams CM. J Insect Physiol 1965b; 11: 803-809.

4. Lockshin RA, Williams CM. J Insect Physiol 1965c; 11: 123-133.

5. Lockshin RA, Williams CM. J Insect Physiol 1965d; 11: 605-610.

6. Lockshin RA. J Insect Physiol 1969; 15: 1505-1516.

7. Wadewitz AG, Lockshin RA. FEBS Lett 1988; 241: 19-23.

8. Lockshin RA, Beaulaton J. Tissue Cell 1979; 11: 803-819.

9. Lockshin RA, Beaulaton J. Histochem J 1981; 13: 659-666.

10. Buttyan R, Zakeri Z, Lockshin RA, Wolgemuth D. Mol Endocrinol 1988; 2: 650-657.

11. Zakeri ZF, Quaglino D, Latham T, Lockshin RA. FASEB J 1993; 7: 470-478.

12. Lockshin RA. Science 1966; 154: 775-776.
} 